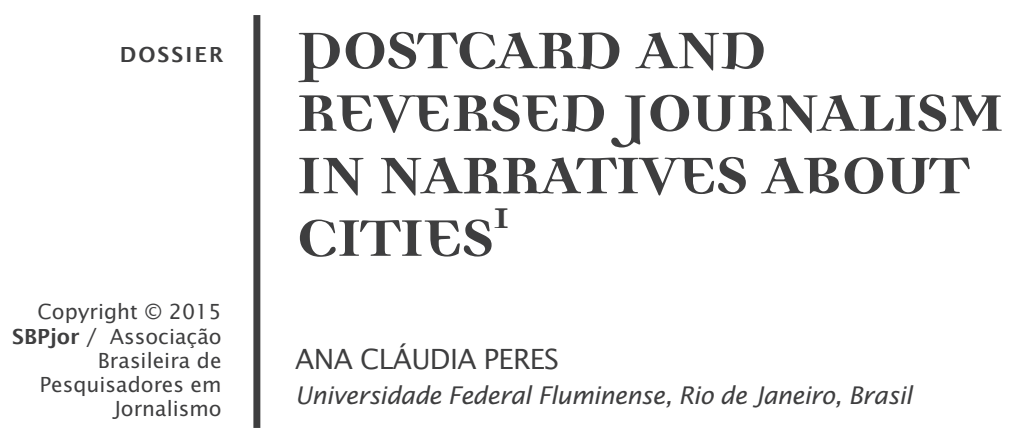

\begin{abstract}
The city is a place of encounters. Journalism often appropriates raw facts and statistic data in order to narrate it. However, there are many ways to understand the urban experience within the field, through accounts that go beyond technical rationality. This paper attempts to understand journalistic narratives as producers of meaning and the city as a text, as proposed by Michel de Certeau. Therefore, we investigate narratives about the city in the magazine piaui as a starting point to examine discursive strategies that by combining the real and the poetic expand the fact, produce dialogues and expose other possible types of journalism. Above all, we aim to provide a reflection on the place that journalism occupies today within the field of knowledge, within an epistemological perspective that considers the material and symbolic, factual and emotional, ethical and aesthetic contexts.
\end{abstract}

Keywords: Journalism. Narrative. Cities. Subjects. Relationship.

\title{
O POSTAL E O AVESSO DO JORNALISMO EM NARRATIVAS SOBRE CIDADES
}

RESUMO - A cidade é um lugar de encontros. Para narrá-la, o jornalismo costuma se apropriar dos fatos brutos e dos dados estatísticos. No entanto, há, nesse campo, inúmeras maneiras de dar a ver a experiência urbana em relatos que extrapolam a racionalidade técnica. Este artigo é uma tentativa de compreender as narrativas jornalísticas enquanto produtoras de sentido e a cidade como um texto, como pretende Michel de Certeau. Para tanto, toma as narrativas sobre cidades da revista piauí como ponto de partida para investigar estratégias discursivas que, ao combinar o real e o poético, ampliam o fato, produzem diálogos e expõem os outros possíveis do jornalismo. Trata-se, antes de mais nada, de provocar uma reflexão sobre o lugar que o jornalismo ocupa hoje no campo do saber, dentro de uma perspectiva epistemológica que considera os contextos material e simbólico, factual e afetivo, ético e estético.

Palavras-chave: Jornalismo. Narrativa. Cidades. Sujeitos. Relação

\section{LA TARJETA POSTAL Y LA INVERSIÓN DEL PERIODISMO E N NARRATIVAS SOBRE CIUDADES}

RESUMEN - La ciudad es un lugar de encuentros. Para narrarla, el periodismo tiende a apropiarse de los hechos brutos y estadísticas. No obstante, hay en este campo, muchas maneras de llegar a ver la experiencia urbana en las histórias que van más allá de la racionalidad técnica. Este artículo es un intento de compreender las narrativas periodísticas como productores de sentido y de la ciudad como un texto, como quieres Michel de Certeau. Por lo tanto, toma los relatos sobre las ciudades en la revista piauí como punto de partida para investigar las estrategias discursivas que mediante la combinación de lo real y lo poético, amplifican el hecho, producen diálogos y exponen los otros posibles del periodismo. Es, ante todo, para provocar la reflexión sobre el lugar que ocupa el periodismo hoy en el campo del conocimiento, dentro de una perspectiva epistemológica que considera los contextos material y simbólico, factual y emocional, ético y estético.

Palabras clave: Periodismo. Narrativa. Ciudades. Sujeto. Relación 


\title{
1 THE JOURNALISTIC GESTURE - AN INTRODUCTION
}

\begin{abstract}
In the bar and restaurant Cantinho dos Servidores ('Public Worker's Corner), with its tile walls and wooden tables lacking table cloths, it is still possible to share a generous size meal for merely 6 Reais. The establishment is located at Sacadura Cabral Street, which marks the line of the ocean which existed until a little over a century ago, when an embankment was built for the construction of Rio de Janeiro's port, in the Guanabara Bay. On a clear day in early September, a group of city planning professor and students from the Federal University of Rio de Janeiro met there for lunch before a surveying visit to the nearby Favela da Providence. Two architects who had recently arrived from Denmark; a boy and a girl, with their faces blushed due to the heat also joined them (ANTUNES, Cláudia, 2013, p. 22)
\end{abstract}

On number one, Silvino Montenegro Street, there is a four-story dirty building, whose sidewalk is taken over by a fetid pond on rainy days, formed by the open sewer. The first impression, as well as the second, is that this is one of the many abandoned buildings in Gamboa, a neighborhood of the desolate Rio de Janeiro Pier. (CARVALHO, 2008, p.43).

The two narratives above have much in common. It is true that these are the opening paragraphs of news articles that aim to read the city within contemporary journalism. But moreover, they are narratives that, in their very fabric, give clues that they intend to travel on a less dogmatic way than the authorized by the canons of hegemonic Journalism. In them, the journalist leaves his ivory tower behind and travels the city streets in texts that without leaving behind technique, make the act of narrating an aesthetic experience, a game with the reader, evidentiating the "how" of journalistic discourse (RESENDE, 2009).

Whether displaying or camouflaging a place of speech, only to later reveal its relevance in the news threads, in these two examples taken here as loan for a reflection on the field of communication in light of the narratives, the journalist talks about city view from the inside, like a maze of reports, a noisy Babel that perhaps due to this, makes itself alive, and features marks from another city and another Journalism. Leaving this route in plain site is only one of the numerous discursive strategies of news production that make the journalistic narrative a path with multiple choices instead of a one-way street, as suggested by traditional journalism, by establishing objective criteria as a narrative device.

Borrowing form Rosana de Lima Soares (2009), we can see in the interdicted something that lays "in between", a "third border" that goes beyond any framework, that is located in between silence 
and the word. Thus, each text can be constituted as "a unique experience and its account conveys both the proof and the evidence of their trajectory with the stumbles and the surprises faced along the way (SOARES, 2009, p.65).

It is fact that in the age of technological innovation - which has caused a revolution in the daily habits and customs - communication is going through huge changes, with the apparatus that promotes real-time information, web-based journalism, online news, which alter the pace of news production and consumption of information and ultimately generate an identity crisis in journalism. In this context, the flood of bureaucratic narratives that are a staple of the factual tone of press coverage attests to what Walter Benjamin predicted, in the 1930s: "Every morning we receive news from around the world, and yet, we lack amazing stories" (1993, p.203).

As Nestor García Canclini (2002) reminds us, in fifty years communication went from the flâneur stroll that used to gather information about the city and then transfer it to his chronicles, to the helicopter flight, which now hovers over the city and offers a lingering panorama of the metropolis through the point view of view of those who those who watch and inform. However, the technology that has been used in favor of disseminating information has generated ever more uniform stories that do not account for the complex process that involves communication between subjects, even if mediated by a machine. Thus, according to Canclini, what we observe are media discourses that do not inspire change and that contribute to reproduce more than to change a social order, while maintaining

[...] A function of mimesis, of compliance with socioeconomic structures and the commonplaces of political culture. Even when they register manifestations of protest and witness inequality, they edit dissident or excluded voices in order to preserve the status quo (CANCLINI, 2002, p.50).

Thus, in agreement with Canclini (2002), we can say that journalism impoverishes the city. By privileging excessive, credible and verifiable information and ignoring the plurality of the reports and the amplitude of the narrative, journalism does not contribute to extend a view of the city. Oftentimes, even if the reports and the voices of discourse are altered, the narrative structures faithfully follow the pre-established model, once again contributing to the reproduction of common sense. 
However, being both a reporter who deals with facts, and a storyteller, are not contradictory activities (TUCHMAN, 1999a). This paper explores the possibility of the real, seen as factual event, and the poetic, as producers of meaning that go beyond instrumental rationality, meeting in contemporary journalism in service of a less superficial communication. Therefore, looking at narratives, particularly at media narratives about the city - this theater of a war on reporting (CERTEAU, 1994) - seems a good way to try to understand the world aiming to locate in these narratives the place of a gesture that promotes meanings and produce dialog.

This is because, even in face of technic, communication and more specifically, journalism take shape through dialogue. The philosopher Vilém Flusser (2007) stated that communication is an interpretive science, not an explanatory science. And that therefore, a theory that focuses on this field has to create meanings and not only produce information. Bringing this theory to the world of doing journalism, we can say that journalism that aims to see and reveal everything behind the mantle of the determined defender of truth, bases himself on an array of numbers and statistics but it produces institutionalized discourses instead of dialogue.

According to Flusser (2007) -the real purpose of human communication is the attempt to overcome death through the company of others - the accumulation of information is "just a sort of trash, dead of the purpose against death" (2007, p.95). Along these lines, before being a will for truth, communication should bring within itself a will for relationship. And in this, to grasp a fact in journalism as if it were something in the world that is independent from the subject of discourse, outside of the communication process, at least. The dialogic journalistic narrative leaves in its path traces, tracks, footprints, signs that they are themselves institutionalizes of realities (SOARES, 2009) and that, as they are followed, they allow readers to reinvent the world.

\section{STILL THE OLD GHOST OF OBJECTIVITY}

One of the principles of the journalistic practice takes objectivity as an ordering principle and lead us to believe that the journalistic narratives produced impartially and with technique 
are able to reflect reality and an absolute truth. Michel Schudson (1978) says that with the ideology of objectivity, "newspapers replaced a simple faith in the facts for procedures created for a world in which even the facts were questioned" (1978, p.122). This is because, due to the effectiveness of public relations and propaganda used during World War I, which put into question the credibility of facts, the newspapers created a set of rules in order to account for the world news.

Gaye Tuchman (1999b) understands journalistic objectivity as a strategic ritual developed by journalists to protect them from the risks of the profession. The author proposes the analysis of some factors that, according to her, influence the perception of objectivity and act as a sort of alibi for the professional. Tuchman alerts to the fact that "journalists call upon the ritual procedures to neutralize potential critics and to follow routines confined by 'cognitive limits of rationality"' (1999b, p.75).

Among the tactics used by journalists to ensure an objective account of events are, according to the author, the use of quotation marks as if the act of putting statements in the mouth of a third party or to counteract different points of views from various sources were enough to ensure such impartiality. However, Tuchman believes that while such procedures can provide demonstrable evidence of an attempt to achieve objectivity, it cannot be said that it is possible to achieve it. The author herself concludes that,

[...] Since objectivity can be understood as a "quality of objects external to thought' and objective as 'that which belongs to the object of thought, not the subjects who thinks' it would be difficult to say - as journalists do - that the presentation of conflicting possibilities fosters objectivity (TUCHMAN, 1999b, p.80).

According to Robert A. Hackett (1999), studies regarding objectivity tend to accept a few assumptions. Among them, the suggestion that facts can be separate from opinions or judgments, and that journalists can be relatively distant from events. However, each story is a compilation of "facts" structured by the journalist based on an evaluation scale that even when following rigorous technical verification, can not be of a different nature but of a subjective character while narrating the events.

Thus, if it is up to the journalist to select the information ibased on a degree of importance chosen by him/her, it is based 
on his version of the facts that what is being narrated will come to light. Even when following formulas as the inverted pyramid and answering at the beginning of the story the classic questions - what, who, how, when, where and why - it is the criteria chosen by the journalist that will prioritize this and not that information in the head or in the body of the text.

Therefore, if we accept that the news are not merely a reproduction of facts nor that journalists are mere spectators of the process, we can say, agreeing with Nelson Teasing, that news happen in the conjunction of event and text. In proposing that the event creates the news and the news, in turn, creates the event, Teasing (1999) makes clear that the journalist is not just a viewer capable of faithfully reproduce what happens in the world and, that the narrative choice made by the journalist is not entirely free:

\begin{abstract}
This choice is guided by the appearance that reality takes to the journalist, by the conventions that shape his/her perception and provide a formal repertoire for the presentation of events, institutions, and routines. Narratives are developed through metaphors, examples, clichés and images (...) The literary and narrative forms ensure that the journalist, under the tyrannical pressure of the time factor, can turn almost instantaneously an event into news (TRAQUINA, 1999, p.169).
\end{abstract}

The journalistic objectivity strategy ignores the fact that every practice is social, discursive and cultural and therefore constructed through language (HALL, 1997). Thus, "even the discourse that aims to uncover the truth, in doing so, constructs their own truth, one among possible others" (Soares, 2009). Thus, agreeing with the statement that everything that appears in the world is constructed via discourse (SOARES, 2009), it can be said that discourse, including journalistic, alters reality, since the narrative invents the world, in order to recreate it. To Rosana Lima Soares, the fiction present in mediated discourses is viewed not in the sense of a lie, but in the sense of manufacturing and creating and thus, "bringing in itself the inability to escape its testimonial side, that is deeply committed and imbricated with the one who speaks" (SOARES, 2009, p.82).

Alonglines the same argument, Smith shows that it is the various instituted discourses that in effect create truth in facts. And that the journalistic discourse that legitimizes itself as objective, neutral and impartial, with all its selection and newsworthiness ${ }^{2}-$ proximity, timeliness, novelty, originality - would be just another of 
these institutionalized discourses. Therefore, we can say that the newspaper would be constituted at the space par excellence of the institutional discourse. However, as discourse, it also has a path, in spite of the set of rules that insists on erasing the traces and leaves out everything that is the rest, the leftovers. This discourse that is created along the way would be the institutional discourse.

By this logic, as well as in urban areas, it cannot be ignored that in fact, a city can only be constructed as far as their inhabitants establish their paths (CERTEAU, 1994). Indeed we dare to say that the institutional discourse modifies the instituted discourse and it is in this space that journalism takes place. According to journalism's instituted discourse, everything is disciplined, clear, and aseptic as a planned city. It turns out that, strictly speaking, the planned city cannot exist except in the imagination of their creators. It is Renato Gomes Lamb who tells us that, "rupturing with rationality is essential for the realization of human potential and their inventiveness (2008, p.25-26). WE can say the same about narratives that make us see cities. The more attached they are to the ordering and institutional discourse that hovers over the urban space; the less plural is the look that they shed on the daily life of cities.

When the city becomes disorganized by the movement of its "ordinary men" (CERTEAU, 1994) the text regarding this city must accompany such a move. It is a subversive text in the sense that it goes against the legitimizing discourse of the established order, present in narratives that when done any other way, only reinforces stereotypes. By exploring the paths in the narrative itself, the journalist who is not entangled by technical intricacies and the ghost of objectivity, provides the reader with a map of possible landscapes for journalism that are no longer limited to framing facts.

\section{POST CARD NARRATIVES VERSUS REVERSED NARRATIVES}

We must face the fact that evidently if there are narratives that frame the city, we can also locate in journalism narratives that have been contaminated by the streets' chaos and their multiple meanings, where the writing challenges and disorients us. In the first case, we are dealing here with texts that we will refer to as "postcards narratives", for illustrative purposes - traditionally accepted by the 
hegemonic discourse and that do not allow for the remnants, the ruins, the garbage, and the leftovers. On the other hand, instead of the neutral and impartial reporting, what is revealed is a narrative composed of a plurality of languages and meanings that draw the urban universe and give way to a city that extrapolates beyond frames. To this other narrating style, which we also locate within the field of journalism, we will refer to it as "reversed narratives", not only because it is the opposite of the postcards and reveal the many cities that exist beyond the visible city and the commonplace. But because within their narrative they break away from the edges of the strict journalistic discourse causing in themselves a strangeness, a difference, an opposite direction.

Let's examine the following narrative:

\begin{abstract}
It was almost nine in the morning on a Friday in March, and the street in front of the stage built in Complexo do Alemão, in Rio de Janeiro, was still empty. On the stage, Wagner Nicácio, president of one of the residents' associations in the region, gave out last minute instructions, "Nilson run over here! We better buy more balloons, fifteen more packages! All white, OK? Go, hurry up! "After a while, President Luiz Inacio Lula da Silva would come to the site to announce the start of the second phase of construction of the "Program for Accelerated Growth" (Programa de Aceleração do Crescimento - PAC), in Rio de Janeiro. (SCARPIN; TARDÁGUILA, 2008, p.25).
\end{abstract}

By starting the narrative with the expectations of the residents of a Rio de Janeiro slum on the eve of the visit of the nation's president, the journalist pulls out the thread of a tangled yarn. To accomplish this, the journalist draws upon his own repertoires, bringing to the surface what he observed in the field, the dialogues, the weather, the gestures, the conflict, the terms, while at the same time, the very texture of information tells us a lot about the urban contrasts. It is through the narrative that the reader is familiarized with the intricate relationships that move the city and that have as protagonists the governors, the police, the drug dealers and the slum's resident's associations.

The text makes use of multiple voices and does not attain itself merely to quotation marks in order to compose the interviewee's profile, thus making each character much more intriguing - as human beings indeed are. In this type of narrative, nothing prevents, for example, that Rosangela Praxedes, the Morro do Alemão resident who was fighting for a spot in the PAC construction, to be presented not just as one number among the 100 other women who rose early 
to stand in line. Even more revealing is knowing that she "dined rice, beans, and liver with potatoes, accompanied by her son and daughter in law, watched the soap opera, and left home with a knapsack: crackers, water, a lawn chair, a pillow and a blanket" (SCARPIN; TARDÁGUILA, 2008, p. 25).

Such details, far from diminishing the accuracy and informative journalistic account, are part of the production process characteristic of language and that as such, are also part of the journalistic discourse. "We cannot understand the journalistic language as a mere strict view of the factual context in which it takes place" (RESENDE, 2002, p.75). This is because the journalistic discourse is not only the objective word, but also a universe of signs that represent and signify. In other words, language constructs realities.

If in the "postcard narratives" objective reality is the only one allowed, in the "reversed narratives", the many possibilities that extrapolate the city frames are taken into account. Drawing from Rosana Lima Soares (2009), we can state that the boundaries of the word delineate the city like the boundaries of a frame define what is inside of it. But after all, if a frame exists, it serves to remind us that, just as there is something that fits within the postcard, it is because so many other landscapes were left out.

In this sense, the framed discourse establishes margins "between the said and the unsaid, between gaps and emptiness" (SOARES, 2009, p.50). In the example of the narrative examined here, the markings of the path traveled by the journalist give us clues of other possibilities, and re-signify the news. As we can observe in this other passage, even a non-interview that would have been banished in a "postcard narrative" for being superfluous, is used in order to enrich the information:

Those who know the infantry colonel Carlos Roberto Sucha say he is a tall man with light skin and eyes, in his late 50s. In 2003, he defended a Masters Thesis in International Relations at the University of Brasilia, regarding the State's image, motivation and behavior. The Director of the 'National Homeland Security Department' (Departamento de Segurança da Presidência da República), he is responsible for ensuring Lula's physical integrity, which includes planning his trips, coming up with strategies for visits, managing crises and giving advice on military and security issues. (O coronel Sucha não quis ser entrevistado.) (SCARPIN; TARDÁGUILA, 2008, p. 25) 
Through this narrating style, the journalist is not content with only an apparent reality, but the narrative unfolds in many layers. This plurality that is in the text, the description of the scenes, the fluid rhythm, the context, the laborious language composing each character and, above all, the traces left by journalist, thus become a denial of "postcard narratives". In the example presented here, the factual is relativized. Rather, what is intended here is to tell life stories stemming form the fact and not about the fact.

We do not ignore journalism's role as the purveyor of factual news. Nor do we minimize the routines to what journalist are submitted to, the pressures of time, the ideological dictates of the media, or even the conceptual and pragmatic differences between the media. It would be naive to disregard the research time as well as the purposes in either case. But we come from the assumption that there are many stories in one and many paths to be taken at the time of narrating them.

Thinking through this logic, let us continue to examine narratives that give rise to a polyphonic city in mazelike-texts offering numerous escaping routes and paths by extending a poetic dimension to the journalistic information itself. The following is an excerpt of another narrative entitled "To Live on the streets of Ipanema" ("Morar na rua em Ipanema-SCARPIN, 2010, p. 26) about "beggars of one of the wealthiest neighborhoods in Brazil" - As described by the headline that rips apart the postcard and allows readers the possibility of further readings.

\footnotetext{
Villas-Boas is very thin, has his skin taken by scabs, several bruises along the legs and, in fact, his stench could be felt from afar. He said he is 16 , but taking into account the dates and the situations he mentions, he is likely to be older. He said he was kicked out of home by his stepfather at five years old and has since lived on the streets.

Since he was 12 years old, he has lived with his wife, Patricia, with whom he has a three-year-old child. She is pregnant again. Villas-Boas met her after "a very cool gringo" gave him this 350 Reais. "I kept looking at her on the beach and when I got the money, we went to McDonald's. We spent it all. Then she saw that I was a nice guy."

For him, the days, months and years on the streets are almost indistinguishable. "I know the clock is ticking when the Bank puts Christmas ornaments on the sidewalk," he said. "There, it is December already. When it is Easter, there are rabbits everywhere “. (SCARPIN, 2010, p. 26, author's emphasis)
} 
Note that, through the narrative, we know one of the characters of the report. Much of the respondent's personality shows through without the reporter's reliance on statistical data that frame the homeless population in a statistical value. There is information and there is a story being told through a rich and unique narrative situation that comes up in detail and lends itself to explore a particular social context. Even when choosing to reproduce the interviewee's speech, there is a subtlety in the choices to reveal something even in what is untold. For example, the statement given by Villas-Boas on the passage of the months of the year, when highlighted by quotation marks, also reveals a discourse that does not need to be written.

All of this is part of a textual strategy that in this case, means the presence of the story's author in the scene, even if the account is not in the first person. Describing the character, their physical characteristics, their "stench felt from afar", or even confronting the real age of the respondent with his perceived age, the narrative leads us to recognize the existence of a third subject, a narrator. These strategies produce a significant shift from bureaucratic narratives towards narratives of resistance.

Let us examine the following sequence from that same narrative, observing the dialogue / interview and the respective roles taken by journalist / interviewee:

At exactly three o'clock, as promised, Mayor Eduardo Paes opened the door to his office, which overlooks the great Central do Brasil clock. He dismissed the press officer ("Go on, I do not need a babysitter") and offered me water and coffee. I asked him what the city intended to do with the beggars taken from the streets.

\footnotetext{
"This is one of the most difficult problems to solve", he said. "It's the kind of area where you do not have a uniform public policy. You are dealing with the drama of individuals, with the craziest stories possible". For Eduardo Paes, there is an unsolvable dilemma between "the humanitarian side and..." - he stopped to choose his words carefully - "... This demand to clean up the city. We have the guy who complains and the guy who thinks they should be permitted. And then you a type of bourgeois clean consciousness engagement: people come and free their soul by distributing soup").
}

Paes was irritated when I asked if the operation would not have the objective of preparing Rio for the World Cup and the Olympics. "Yeah, put in there that it is because of the World Cup, the Olympics", he said sarcastically. Now all we do is because of it. Today's sheltering is just due to 2016. After that they can all go back to street (SCARPIN, 2010, p.30, author's emphasis) 
Once again we have access to the path, like a thread running through the maze of the polyphonic narrative about an event in a humanized city. We know the backstage, peek at what is behind the scenes, we disclose environments and personalities from the journalist's eyes - if not through the narrative, how else could this be possible? This narrator-journalist was the one who saw Central do Brasil's clock in the room where the dialogue took place, and who furthermore, noticed and later reported, on the interviewee's state of mind, Mayor Eduardo Paes: punctual and attentive at first, offering water and coffee to the reporter; later available but impolite, when dismissing the press officer in an ironic way ("go in, I do not need a babysitter"); revealing himself to be angry and sarcastic when faced with the reporter's questions. Far from compromising the credibility pact between journalist and reader, this strategy on the contrary, helps to establish a rapprochement between the subjects of discourse.

Knowing that the interviewee hesitated before proceeding with his answer, as we were led to see in the narrative through the suspension of the quotation marks - including the use of reticence and a direct interference by the narrator informing of the interruption - offers the reader another possibility to reframe the fact. The narrative itself undertook the task of putting together the pieces of the puzzle. The truths - or lack thereof are not necessarily in quotes. Here, the contradiction is revealed in the very texture.

In this case, unlike traditional journalistic narrative, quotes serve less to signal a response from an interviewee and more to highlight an established dialogue point between reporter and interviewee. In other words, the opposing side is not only heard in order to fulfill a rule of journalism or to counter evidence. The other side is drawn in the narrative itself, where the relationship happens. In this sense, meanings explode within the text. However, it is likely that all of that information, essential in a "reversed narrative" would be undervalued or erased as marks in a "postcard narrative". 


\section{FINAL CONSIDERATIONS}

In analyzing narratives about cities trying to locate in journalism a place for the production of meaning, we encountered a dialogic and polyphonic journalism, like a city itself. Although structured under the baton of a discipline instituted by an authoritarian logic, cities are transformed daily by the action of its common men. Likewise, despite Journalism's desire for ordering the world, its multitude of narratives points to a much richer and plural practice, where what is devious and in disarray also fit.

Along the path down the maze of texts that make up the urban space in the contemporary press, it is easy to locate narratives that continue to be tied to technical rationality, objective data and schematic models that end up generating a text about the city that reveals itself to be authoritarian and reductionist. On the other hand, we also identify narratives that can approach poetic utterances and value the symbolic story of the city, bringing to light the reverse of the scene, stemming from what is fleeing, the residues, the leftovers. These are, respectively, of what we have named in this article the "postcard narratives" and the "reversed narratives" that co-exist not as parallel tracks but as intersecting within the journalistic field itself.

Even if within the "reversed narratives" the attempt of making sense of the world I also present, legacy of a practice guided by a realistic aesthetic, there is not in such cases, an intention to delete the various paths taken. Thus, the path is valued in the text as a major tool for an inter-discursive relationship, and not merely rhetoric, which causes a difference in the field of Communication and contributes to change the journalism map framed by boarders. The contemporary Communication scenario is no longer about grasping what is real and providing absolute truths, but about perceiving the differences, recognizing otherness and shortening the distances between the many subjects of communication.

Parallel to this finding, there is another one, of an epistemological nature: A Journalism that moves away from the rational and towards the affective tends to transform the technique in favor of the narrative, not limiting itself to reporting facts but valuing the fabric of information, the way of narrating. 
It is precisely in telling life stories, and shedding light to various realities and not just a single one, that Journalism is justified as a relational space, affecting individuals, enabling encounters. To narrate, thus becomes important because it is a way of making sense of the world.

\section{Notes}

1 A version of this paper was presented in the Comunicação Coordenada session "People and places in contemporary JOurnalism", in the 12th Encontro Nacional de Pesquisadores em Jornalismo (The National Meeting of Journalism Researchers - SBPjor), at Universidade de Santa Cruz do Sul, from November 6th to 8th, 2014.

2 For didactic purposes it is Worth mentioning the classification of "valores-notícia" (newsworthyness), as the criteria that journalists use when deciding whether an event is newsworthy or not, a type of stamp that defines whether a fact can lead to a narrative (SODRÉ, 2008). According to Nelson Traquina (2009), newsworthyness can be of substantive order: death, fame, proximity, relevance, novelty, notability, the unexpected, the conflict / controversy and the offense; and of contextual order: availability, balance, visuality, competition and the news day.

\section{Referências}

ANTUNES, Cláudia. Os descontentes do Porto. piauí, Rio de Janeiro, n. 76, p. 22-28, jan. 2012.

BENJAMIN, Walter. O narrador: considerações sobre a obra de Nikolai Leskov. In: BENJAMIN, Walter. Magia e técnica, arte e política: ensaios sobre literatura e história da cultura. 6. ed. São Paulo: Brasiliense, 1993. p. 197-221. (Obras Escolhidas). V. 1.

CANCLINI, Nestor Garcia. Cidades e cidadãos imaginados pelos meios de comunicação. Opinião Pública (online), Campinas,Vol. VIII, n.1, 2002, p. 40-53. Disponível em <http://www.scielo.br/pdf/op/ v8n1/14873.pdf $>$. Acesso em mai. 2014. 
CARVALHO, Luiz Maklouf. O caçador de milícias. piauí, Rio de Janeiro, n. 27, p. 42-46, dez. 2008.

CERTEAU, Michel. A invenção do cotidiano 1: artes de fazer. Petrópolis/RJ: Vozes, 1994.

FLUSSER, Vilém. O mundo codificado: por uma filosofia do design e da comunicação. São Paulo: Cosac Naify, 2007.

GOMES, Renato Cordeiro. Todas as cidades, a cidade: literatura e experiência urbana. Rio de Janeiro: Rocco, 2008.

HACKETT, Robert A. Declínio de um paradigma? A parcialidade e a objetividade nos estudos dos media noticiosos. In: TRAQUINA, Nelson (Org.). Jornalismo: questões, teorias e “estórias". Lisboa: Vega, 1999. p. 101-130.

HALL, Stuart. A Centralidade da cultura: notas sobre as revoluções culturais do nosso tempo. IN: Educação e Realidade. 1997.

MEDINA, Cremilda. Ciência e jornalismo: da herança positivista ao diálogo dos afetos. São Paulo: Summus Editorial, 2010.

RESENDE, Fernando. Cidades, culturas e narrativas: espaços de negociação e produção de sentidos. In: MAIA, João; HELAL, Carla (Org). Comunicação, arte e cultura na cidade do Rio de Janeiro. Rio de Janeiro: Eduerj. 2012.

O jornalismo e suas narrativas. As brechas do discurso e as possibilidades do encontro. Revista Galáxia, São Paulo, n. 18, p.3143, dez. 2009. Disponível em: <http://revistas.pucsp.br/index.php/ galaxia/article/view/2629/1671>. Acesso em: mai. 2014.

.Textuações: ficção e fato no ovo Jornalismo de Tom Wolfe. São Paulo: Annablume/Fapesp, 2002.

SCHUDSON, Michael. Discovering the news. New York: Basic books, 1978.

SCARPIN, Paula. Morar na rua em Ipanema. piauí, Rio de Janeiro, n. 44, p. 24-30, mai. 2010.

; TARDÁGUILA, Cristina. Elos perdidos. piauí, Rio de Janeiro, n. 22, p. 24-28, jul. 2008.

SOARES, Rosana de Lima. Margens da comunicação: discurso e mídias. São Paulo: Annablume, 2009.

SODRÉ, Muniz. A Narração do fato: notas para uma teoria do acontecimento. Petrópolis: Vozes, 2009.

TRAQUINA, Nelson. As notícias. In: TRAQUINA, Nelson (Org.). 
Jornalismo: questões, teorias e "estórias". Lisboa: Vega, 1999. p. 167176.

TUCHMAN, Gaye - Contando "estórias". In: TRAQUINA, Nelson (Org.). Jornalismo: Questões, teorias e “estórias". Lisboa: Vega Editora, 1999a. p. 258-262.

A objectividade como ritual estratégico: uma análise das noções de objectividade dos jornalistas. In: TRAQUINA, Nelson (Org.). Jornalismo: questões, teorias e “estórias". Lisboa: Vega, 1999b. p. 74-90.

Ana Cláudia Peres is a PhD candidate in Communication at the Universidade Federal Fluminense (UFF). She is a journalist and holds a Master's degree in Media, Culture, and Meaning Production from the same institution. E-mail: anaclaudia.peres@gmail.com 